\title{
Genetic diversity of eukaryotic ultraphytoplankton in the Gulf of Naples during an annual cycle
}

\author{
Sarah M. McDonald ${ }^{1,3, *}$, Diana Sarno1 ${ }^{1}$, David J. Scanlan ${ }^{2}$, Adriana Zingone ${ }^{1}$ \\ ${ }^{1}$ Stazione Zoologica Anton Dohrn, Villa Comunale, 80121 Naples, Italy \\ ${ }^{2}$ Department of Biological Sciences, University of Warwick, Gibbet Hill Road, Coventry CV4 7AL, UK
}

${ }^{3}$ Present address: Monterey Bay Aquarium Research Institute, 7700 Sandholdt Road, Moss Landing, California 95039-9644, USA

\begin{abstract}
Eukaryotic ultraphytoplankton $(<5 \mu \mathrm{m})$ are an important component of phytoplankton populations. Dot blot hybridisation analysis using class level 16S rRNA gene probes as well as clone libraries were used to investigate the diversity of these ultraphytoplankton during a 15 mo period (2003 to 2004) in the Gulf of Naples. Hybridisation data showed the presence of 3 main classes, Cryptophyceae, Chrysophyceae and Prymnesiophyceae, along with lower signals from the Pelagophyceae. Clone libraries also contained these 4 classes as well as sequences from the Dictyochophyceae, Bacillariophyceae and Prasinophyceae. However, the Prymnesiophyceae gave the dominant hybridisation signal and constituted the majority of each clone library. Their diversity, with a total of 190 sequences belonging to 114 operational taxonomic units (OTUs), probably allows them to dominate the ultraphytoplankton throughout the whole year under differing environmental conditions. Over 100 of these OTUs were unique to different libraries, suggesting a succession of different taxa during the year. The Cryptophyceae were present most of the year with 1 OTU, corresponding to a Plagioselmis prolonga strain from the Gulf of Naples, being the dominant taxon $(28 \%$ of sequences). A striking result was the high hybridisation signal from the Chrysophyceae, which showed a preference for the summer months. The Pelagophyceae were present between December and March. Most $(80 \%)$ of the sequences found in the clone libraries were not identical to available 16S rRNA gene sequences, indicating a high amount of hidden diversity for these algal classes. However, sequences from Prasinophyceae Clade II (Mamiellales) were not detected in the clone libraries.
\end{abstract}

KEY WORDS: Photosynthetic eukaryotes - Ultraphytoplankton - Plastid 16S rRNA gene $\cdot$ Gulf of Naples $\cdot$ PCR

\section{INTRODUCTION}

Autotrophic eukaryotic cells $<5 \mu \mathrm{m}$ in size (ultraphytoplankton) have been observed in the plankton for more than a century (see Johnson \& Sieburth 1982 and references therein) and their importance in primary production has been recognised in vast areas of the world's oceans ( $\mathrm{Li}$ et al. 1983). Assessment of diversity within this fraction is difficult for a number of reasons. Ultraphytoplankton morphology is simple; most cells are little 'balls' (Potter et al. 1997) and many are destroyed or distorted by fixation. Although their pigments can give some idea of taxonomic class, diagnosis using chemotaxonomy is often equivocal (Sym \& Pien- aar 1993, Jeffrey \& Wright 1994, Andersen et al. 1996) Enrichment and serial dilution cultures can give a biased view of diversity as they detect only those organisms that grow well in culture (Johnson \& Sieburth 1982). Recent genetic studies have highlighted the taxonomic diversity of these small cells (Rappé et al. 1995, Potter et al. 1997, Díez et al. 2001a,b, Moon-van der Staay et al. 2001, Medlin et al. 2006), including revealing new classes and novel lineages (Guillou et al. 1999, Massana et al. 2002). Most of these studies have assessed diversity along transects, giving snapshots of the presence of major groups and showing spatial patterns in their distribution. Temporal variations of eukaryotic ultraphytoplankton have 
thus far received meagre attention, the only exception being a molecular study on material from the Helgoland Time Series (Medlin et al. 2006).

The Mediterranean Sea has been the site of numerous early investigations on ultraphytoplankton, with many species having been described from the area and never recovered again (Throndsen \& Zingone 1994). The importance of small eukaryotic algae has been shown at different sites (Bec et al. 2005, Charles et al. 2005), including the Gulf of Naples where 'undetermined phytoflagellates $<10 \mu \mathrm{m}$ ' have been quantified during various studies within the MareChiara (MC) Long-Term Ecological Programme (LTEP) conducted since 1984 (Carrada et al. 1980, Marino et al. 1984, Ribera d'Alcalà et al. 2004). In terms of biomass, these small flagellates comprise the third largest contribution after the diatoms and the dinoflagellates and, along with diatoms, dominate throughout the year at the MC station, where they exhibit wide fluctuations on a weekly scale (Ribera d'Alcalà et al. 2004). Previous investigations (e.g Throndsen \& Zingone 1994, Zingone et al. 1999a,b, Cerino \& Zingone 2006) have focused on restricted groups using serial dilution cultures, while flow cytometry was used to quantify the eukaryotic fraction without identifying the major groups (Casotti et al. 2001).

In this study we assessed the genetic diversity of ultraphytoplankton in the Gulf of Naples using 16S rRNA gene probes (Fuller et al. 2006a) during a $15 \mathrm{mo}$ period with 2 main questions: (1) What are the most abundant groups of ultraphytoplankton? and (2) Are there any changes in the class composition of this fraction over time? Clone libraries were also constructed to explore the diversity of this size fraction at the species level and to investigate whether the same species were present at different times of the year. Since the average cell size of the undetermined flagellates observed in the Gulf of Naples is around $4 \mu \mathrm{m}$, but most are smaller, we chose the size fraction $<5 \mu \mathrm{m}$ and referred to this as the ultraphytoplankton following the definition used by Li et al. (1993) to avoid confusion with the term picoplankton that is usually defined as $<2 \mu \mathrm{m}$.

\section{MATERIALS AND METHODS}

Sampling. Stn $\mathrm{MC}\left(40^{\circ} 48.5^{\prime} \mathrm{N}, 14^{\circ} 15^{\prime} \mathrm{E}\right)$ was sampled weekly from July 2003 to September 2004 as part of the MC LTEP (Ribera d'Alcalà et al. 2004). Surface samples were collected using 12 l Niskin bottles mounted on a Carousel sampler. Salinity and temperature data were obtained using a SBE 911plus CTD profiler (SeaBird). Nutrient data, kindly provided by the Office of Management and Ecology of Temperate and Polar Coastal Areas, were obtained as described in
Ribera d'Alcalà et al. (2004). For phytoplankton enumeration, samples were fixed using a final concentration of $0.8 \%$ neutralised formaldehyde. Depending on the richness of the samples, cells from samples between 1 and $50 \mathrm{ml}$ were viewed under an inverted light microscope at $400 \times$ magnification and counted by means of the method outlined in Ribera d'Alcalà et al. (2004). For molecular analyses, 51 of seawater were pre-filtered through a $90 \mathrm{~mm}$ diameter, $5 \mu \mathrm{m}$ pore size, polycarbonate (PC) filter using a vacuum pump at $200 \mathrm{~mm} \mathrm{Hg}$. The filtrate was filtered through a $90 \mathrm{~mm}$ PC filter of $0.2 \mu \mathrm{m}$ pore size for $1 \mathrm{~h}$. The $0.2 \mu \mathrm{m}$ filter was cut into sections, placed in Eppendorf microcentrifuge tubes, frozen immediately in liquid nitrogen and stored at $-80^{\circ} \mathrm{C}$.

DNA extraction and amplification. DNA was extracted from the stored filter using N-cetyl N,N,Ntrimethylammonium bromide (CTAB) extraction buffer (2\% CTAB, $200 \mathrm{mM}$ Tris $\mathrm{HCl} \mathrm{pH}$ 8.0, 50 mM EDTA, $1.4 \mathrm{M} \mathrm{NaCl}$ and $2.5 \%$ polyvinyl pyrrolidone [PVP]) incubated at $65^{\circ} \mathrm{C}$ for $45 \mathrm{~min}$ before protein removal using at least 2 extractions with chloroform-isoamyl alcohol (24:1) (Doyle \& Doyle 1987, McDonald et al. 2007). DNA was precipitated using isopropanol at $-20^{\circ} \mathrm{C}$ for $1 \mathrm{~h}$. Approximately $830 \mathrm{bp}$ of the $16 \mathrm{~S}$ rRNA gene of marine algal plastids was amplified using PLA491F (Fuller et al. 2006b), which is designed to be biased towards photosynthetic eukaryotes and exclude cyanobacteria, and the oxygenic phototroph reverse primer OXY1313R (West \& Scanlan 1999).

Amplification was carried out in a total reaction volume of $50 \mu \mathrm{l}$ containing $1 \mu \mathrm{l}$ of environmental DNA (approximately $40 \mathrm{ng}$ ), $200 \mu \mathrm{M}$ deoxynucleoside triphosphates, $1.1 \mathrm{mM} \mathrm{MgCl}, 1 \mathrm{mg} \mathrm{ml}^{-1}$ bovine serum albumin (BSA) (Sigma), $1 \mu \mathrm{M}$ each primer and $2.5 \mathrm{U}$ Taq polymerase in $1 \times$ enzyme buffer - Mg (Roche Diagnostics). The reaction conditions comprised $80^{\circ} \mathrm{C}$ for $4 \mathrm{~min}$ followed by 30 cycles of $94^{\circ} \mathrm{C}$ for $30 \mathrm{~s}, 62^{\circ} \mathrm{C}$ for $30 \mathrm{~s}$ and $72^{\circ} \mathrm{C}$ for $40 \mathrm{~s}$, with a final extension of $5 \mathrm{~min}$ at $72^{\circ} \mathrm{C}$. PCR products were purified using a QIAquick PCR purification kit (Qiagen) following the manufacturer's instructions, quantified on an agarose gel and stored at $-80^{\circ} \mathrm{C}$.

The 16S rRNA gene from taxa belonging to the Cryptophyceae, Prasinophyceae clade II (Mamiellales) and Prymnesiophyceae (Table 1) was sequenced using the OXY359F (West \& Scanlan 1999)-OXY1313R primer pair because this gives a slightly longer fragment than PLA491F and allowed the region of the PLA491F primer to be checked for mismatches. DNA extraction, PCR mix and cycle were identical to those for the environmental samples, except that the concentration of $\mathrm{MgCl}_{2}$ was $1.5 \mathrm{mM}$ and the annealing temperature was $55^{\circ} \mathrm{C}$. Sequencing reactions were performed as described in 'Clone libraries' below. 
Table 1. Cultures sequenced during this study. DNA for the Cryptophyceae cultures was provided courtesy of Federica Cerino. Bente Edvardsen supplied the DNA for the Prymnesiophyceae indicated with an asterisk $\left({ }^{*}\right)$. The other cultures were held within the SZN culture collection. DNA was extracted using the CTAB method outlined in the section 'DNA extraction and amplification'. GON $=$ Gulf of Naples

\begin{tabular}{|lll|}
\hline Species & Strain & Collection location and date \\
\hline Cryptophyceae & & \\
Cryptochloris sp. & C94 & Salerno 8 Jul 2002 \\
Hemiselmis sp. & C15 & Naples, MC 28 Oct 2003 \\
Plagioselmis prolonga & C27 & Naples, MC 18 Jun 2002 \\
Proteomonas sulcata & C28 & Salerno 8 Jul 2002 \\
Rhinomonas pauca & C5 & Naples, MC 4 Sep 2002 \\
Rhodomonas sp. 3 & C42 & Naples, MC 18 Dec 2001 \\
Prasinophyceae Clade II & & \\
Micromonas pusilla & PART & Stn Partenope, GON 8 Jan 1997 \\
M. pusilla & MP1 & MC 8 Apr 1993 \\
M. pusilla & MP2 & MC 24 Nov 1993 \\
M. pusilla & MPCO & Stn Castel dell'Ovo, GON 21 Nov 1996 \\
M. pusilla & P7/1 & Sicily 15 May 1992 \\
M. pusilla & Norbal & Stn 14S N Balearics 9 Mar 2003 \\
Prymnesiophyceae & & \\
Chrysochromulina acantha* & UIO T20 & S Norway 1994 \\
C. aff. polylepis* & PLY200 & English Channel 1958 \\
C. campanulifera* & UIO J10 & Skagerrak, S Norway 1984 \\
C. cymbium* & UIO R18 & Off Arendal, S Norway 1992 \\
C. herdlensis* & CCMP284 & North Pacific 21 Apr 1976 \\
C. hirta* & hi-1 & Off Austevoll, W Norway 1989 \\
C. leadbeateri* & UIO TJE & Loften, N Norway 1991 \\
C. rotalis* & UIO TH2 & Skagerrak, S Norway 1990 \\
C. simplex* & UIO JomfB & Oslofjord, S Norway 1989 \\
C. throndsenii* & UIO K11 & Off Arendal, S Norway 1989 \\
Dicrateria inornata* & CCMP355 & Unknown 1962 \\
Emiliania huxleyi* & UIO BOF & Oslofjord, S Norway \\
Imantonia rotunda* & UIO 101 & Off Arendal, S Norway 1994 \\
Isochrysis cf. galbana* & UIO Ryfylke & Ryfylke, W Norway 1990 \\
Phaeocystis cordata & Phaeonap 1 & MC 15 Mar 1991 \\
P. globosa & Naples & MC 16 Mar 1999 \\
P. jahnii & B5 & MC 6 Mar 1996 \\
Phaeocystis sp. & MC679 & MC 30 Aug 2005 \\
& & \\
& & \\
\hline
\end{tabular}

bridisation was quantified using a Fujifilm FLA-5000 phosphorimager and Total Lab software (Phoretix). Relative hybridisation (\%) was calculated as previously described (Fuller et al. 2003). The relative hybridisation of a given specific probe compared with that of the eubacterial probe (EUB908, Edwards et al. 1989) to the control DNAs was averaged where more than 1 control DNA was used. Any sample giving a signal above $2 \%$ was considered as being above background.

Clone libraries. Six clone libraries were constructed from PCR products obtained with the PLA491F-OXY1313R primer pair using a TOPO TA Cloning ${ }^{\circledR}$ kit (Invitrogen ${ }^{\mathrm{TM}}$ Life Technologies) for 28 October (library MC597) and 1 December 2003 (MC601), and 9 February (MAMA64), 25 March (250304), 17 May (MC615) and 6 July (MC622) 2004. These PCR products were from different reactions than the products used for the dot blot hybridisations. The MC615 May library corresponded to the period of maximum total phytoplankton species abundance for Stn MC (Ribera d'Alcalà et al. 2004). The remainder of the libraries corresponded to dates when the sum of the signals from the specific probes was the lowest in comparison with the eubacterial probe. Each library was constructed using 96-well plates (see Table 2 for numbers of useful sequences). Plasmid purification was obtained in high throughput using the Mil-

Dot blot hybridisations. Control DNA for the dot blot hybridisations was prepared from PCR products from strains corresponding to each specific probe obtained from the Provasoli-Guillard National Center for Culture of Marine Phytoplankton (CCMP) and the Roscoff Culture Collection (RCC) (purified 16S rRNA gene PCR products were kindly provided by Dr. Nick Fuller; for a list of strains used see Fuller et al. 2006b) and amplified using the same primer pair and PCR conditions as for the environmental samples before purification in the same manner.

Dot blot hybridisations were carried out using the method outlined in Fuller et al. (2003) and the following algal class-specific 16S rRNA gene oligonucleotide probes: CHLA768, CHRY1037, CRYP862, EUST985, PAVL665, PELA1035, PING1024, PRAS826, PRYM666 and TREB708 (see Fuller et al. 2006a for details of probe sequence and dissociation temperature). Hy- lipore Montage Plasmid Miniprep Kit and a robotic station, Beckman Coulter's Biomek ${ }^{\circledR}$ FX Laboratory Automation Workstation, equipped with $\mathrm{ORCA}^{\circledR}$ robotic arm. Sequence reactions were obtained with the BigDye Terminator Cycle Sequencing technology (Applied Biosystems), purified in automation using the Millipore Montage SEQ 96 Sequencing Reaction Cleanup Kit and the Biomek FX. Products were analysed on an Automated Capillary Electrophoresis Sequencer 3730 DNA Analyzer (Applied Biosystems). Coverage of each clone library (Romari \& Vaulot 2004) was calculated using $1-\left(N_{\mathrm{c}} / N\right)$, where $N_{\mathrm{c}}$ is the number of cumulative unique sequences and $\mathrm{N}$ is the number of useful sequences (excluding primer dimers, chimeras, those clones for which there was no reliable sequence and prokaryote sequences). Rarefaction curves (Romari \& Vaulot 2004) were plotted to illustrate how accurately each library sampled the diversity of each sample. 
Phylogenetic analyses. Contigs from forward and reverse sequences were constructed using Seqman II 3.61 (DNASTAR) and aligned using ClusterW in BioEdit 7.0.1. Alignments of sequences from each clone library, including the sequences from the control DNA, were analysed using preliminary neighbour joining (NJ) trees with uncorrected ' $p$ ' distances to identify the class of each library sequence and the proportion of each class found in the libraries. The more obvious chimeric sequences, detected by examining the alignment by eye, were removed from the analysis. Separate analyses were carried out for sequences for the Chrysophyceae, Cryptophyceae and Prymnesiophyceae and finally the remaining sequences, including additional sequences from members of those classes from both the GenBank and the ARB databases and from the newly sequenced species in an attempt to identify the sequences to species. The respective alignments were analysed in PAUP* using the modelblock PAUPb10 from Modeltest 3.7 to assess the best-fit substitution model. The likelihood settings generated by Modeltest for the best-fit model were used to construct NJ trees using PAUP*. Trees were rooted at the midpoint. Bootstrap analyses were performed using 1000 replicates and the same likelihood settings. Long branches were suspected to be chimeric and so investigated by analysing sections of the sequences using BLAST to check for regions that aligned to different organisms. In some cases, only short sections of the sequence, which were difficult to align, blasted to a phylogenetic group significantly different from the rest of the sequence. These sequences were removed from the analysis. Sequences were grouped into the same operational taxonomic units (OTUs) if they had more than $99 \%$ similarity.

The sequences reported in this paper have been deposited in the GenBank database under accession numbers EF051737 to EF051766 for algal cultures, and EF051767 to EF052253 for environmental clones.

\section{RESULTS}

\section{Phytoplankton counts and environmental data}

Total eukaryotic phytoplankton abundance was rather low in winter (Fig. 1A), with peaks of abundance during the summer months that generally coincided with low salinity values and peaks in nutrient concentrations. During these peaks, a considerable fraction of the populations comprised small sized (5 to $15 \mu \mathrm{m}$ ) diatoms and naked dinoflagellates. The abundance of eukaryotic ultraphytoplankton followed the same pattern, but this fraction formed a greater proportion of the total in winter than in summer. For example, the
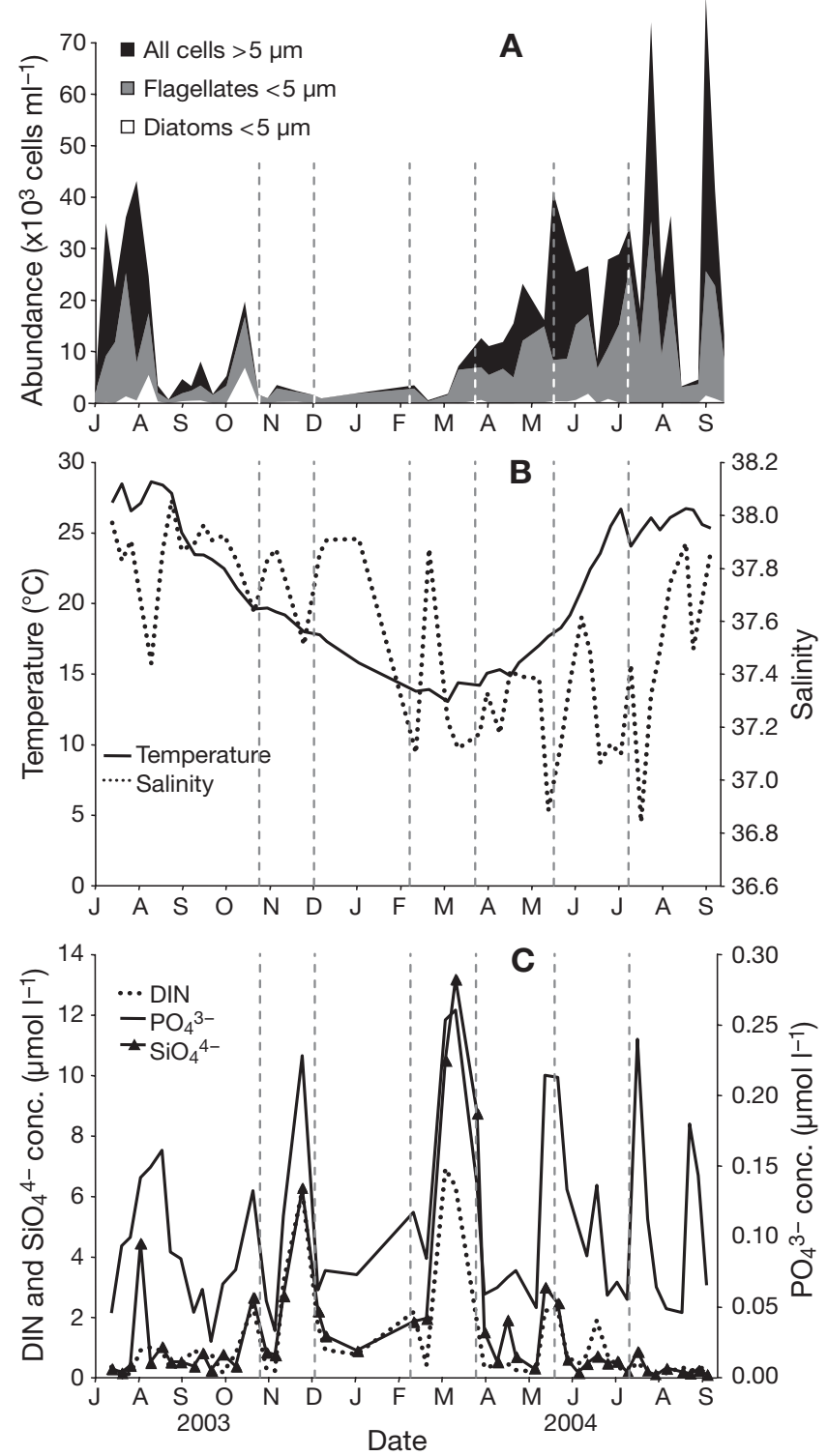

Fig. 1. (A) Eukaryotic phytoplankton abundance, (B) CTD measurements and $(\mathrm{C})$ nutrient concentrations in the Gulf of Naples showing the variation during the study period, July 2003 to September 2004, courtesy of the Office of Management and Ecology of Temperate and Polar Coastal Areas SZN. Vertical dashed lines indicate the dates for which clone libraries were constructed. The only groups $(<5 \mu \mathrm{m})$ easily identified and significantly abundant in the eukaryotic phytoplankton counts are 'flagellates' and diatoms

eukaryotic ultraphytoplankton accounted for $96 \%$ of the total on 17 December 2003, but only $20 \%$ on 17 May 2004. The abundance of small diatoms showed peaks during the year, e.g. in August and October 2003, which were mainly due to Skeletonema menzelii, Cyclotella atomus, Minidiscus sp. and other centric species $<5 \mu \mathrm{m}$. These small diatoms, along with a general group 'flagellates', are the only small cells that can be identified using light microscopy. During the 
study period, the Stn MC was characterised by temperature and salinity values ranging from 12.98 to $28.55^{\circ} \mathrm{C}$ and 36.84 to 38.05 , respectively, with frequent fluctuations in salinity (Fig. 1B). Nutrient concentrations showed large variations during the year, with dissolved inorganic nitrogen (DIN) and $\mathrm{SiO}_{4}{ }^{4-}$ minima generally found in summer (Fig. 1C). However, during the summer months, there were frequent peaks of nutrient input, for example on 17 May, 22 June, 20 July and 25 August when nutrient levels were comparable with those in December.

\section{Dot blot hybridisations}

Of the 10 algal class-specific oligonucleotide probes used, only 4 gave percent relative hybridisation values above background. These were probes PRYM666 (Prymnesiophyceae), CRYP862 (Cryptophyceae), CHRY1037
(Chrysophyceae) and PELA1035 (Pelagophyceae) (Fig. 2). The PRYM666 probe gave a signal in all samples throughout the sampling period with a minimum signal of $1.7 \%$ on 28 October 2003 , a maximum signal of $61 \%$ on 16 February 2004 and an average of $35 \%$ relative hybridisation over the year. Similarly, cryptophytes were detected in most samples with the highest relative hybridisation signal of $45 \%$ on 4 March 2004 and a generally low signal during the summer and early autumn of 2003 that was not repeated the following year. Peaks in relative hybridisation were also seen during November, March, May, July and the end of August. Chrysophytes were most readily detected during the summer months of both years, with the highest relative hybridisation signal of $64 \%$ during September 2003 and a general low during the winter. The Pelagophyceae probe gave hybridisation signals above background on only 6 dates between December 2003 and late March 2004 (Fig. 2), with a peak of $6.75 \%$ on 2 February 2004 .

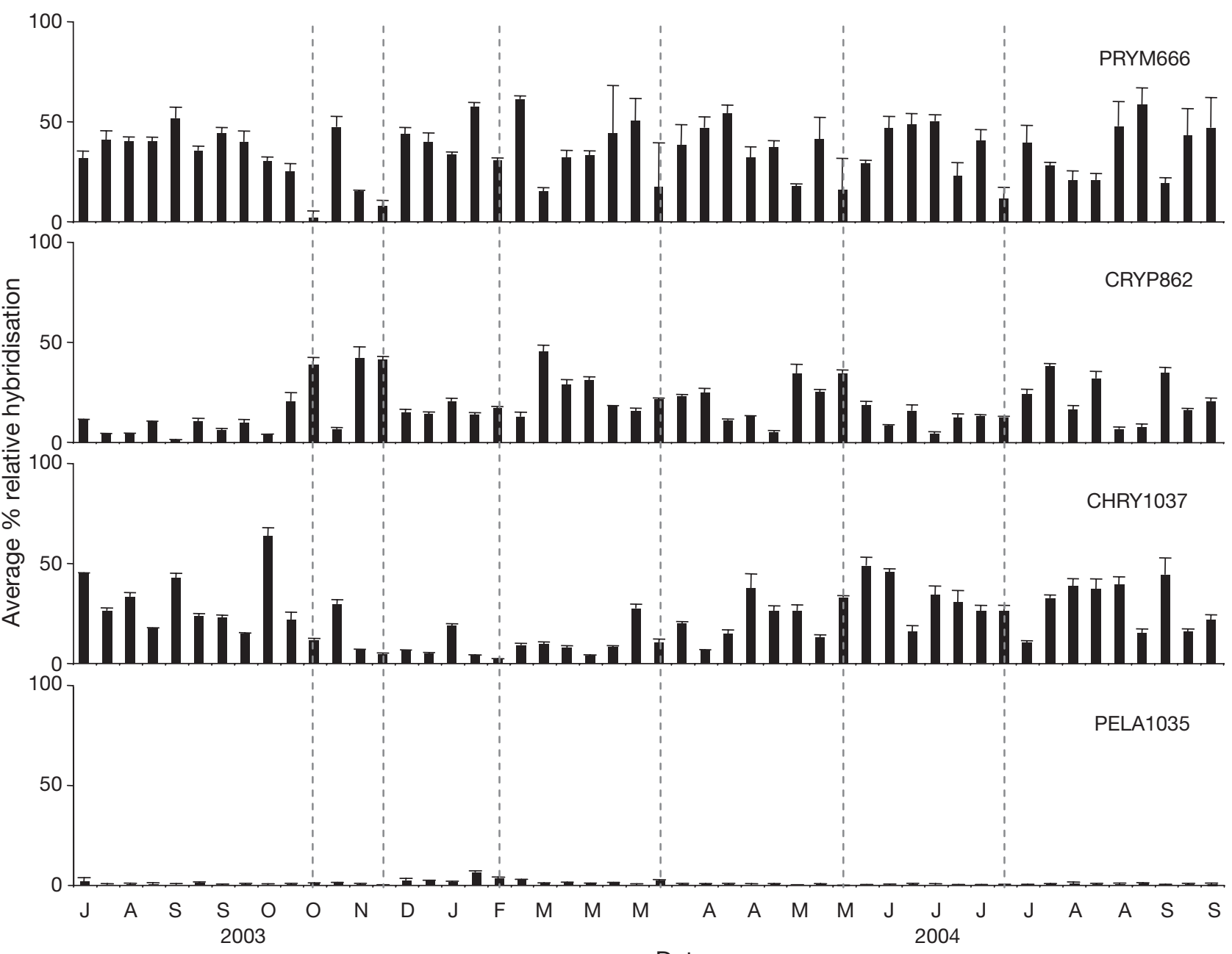

Date

Fig. 2. Dot blot hybridisation data for the 4 algal class-specific 16S rRNA gene oligonucleotide probes that gave signals above background (presented as a proportion of all amplified by primers PLA491F and OXY1313R). Error bars indicate SD between triplicate samples and vertical dashed lines indicate the dates for which clone libraries were constructed 


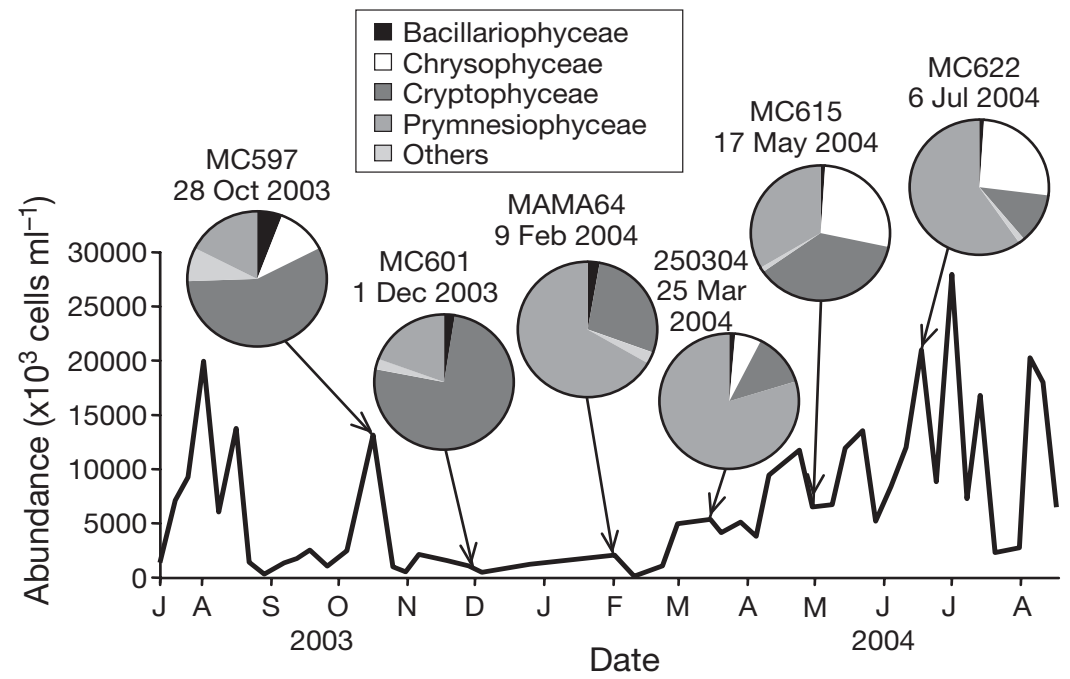

Fig. 3. Proportions of each taxonomic class found in the 6 libraries displayed above the abundance of ultraphytoplankton; arrows point to the dates of each library. 'Others' category includes Dictyochophyceae, Pelagophyceae and Prasinophyceae

\section{Clone libraries}

The classes found within clone libraries were very similar to those found using the class-specific oligonucleotide probes (Fig. 3). Higher class level taxonomic diversity was found during winter when total abundance was lower. The reverse occurred during summer, with dominance by only 3 classes: Chrysophyceae, Cryptophyceae and Prymnesiophyceae. Chrysophyceae sequences were not present in the 2 winter libraries (MC601 and MAMA64), but were well represented in spring and summer. Pelagophyceae sequences were only found in the February library, corresponding to the period in which the PELA1035 probe gave the highest hybridisation signal. Sequences from classes for which 16S rRNA probes are not currently available were also found, for example, for Prasinophyceae clades I (Pyramimonadales) and for Dictyochophyceae. The presence of diatom sequences in the October library reflected the peak detected by cell counts (Fig. 1A).

Rarefaction curves (Fig. 4) indicated how well the diversity within a sample was assessed by the number of clones examined. None of the libraries reached saturation, meaning that the diversity within each sample was not fully sampled. However, the curves for the autumn and winter libraries were less steep, whereas that for the February and March libraries (MAMA64 and 250304), corresponding to the period of the spring bloom, was the steepest. The coverage values (Table 2) also indicated that the March library was the least well covered, as the number of OTUs recovered was high in relation to the number of clones examined.

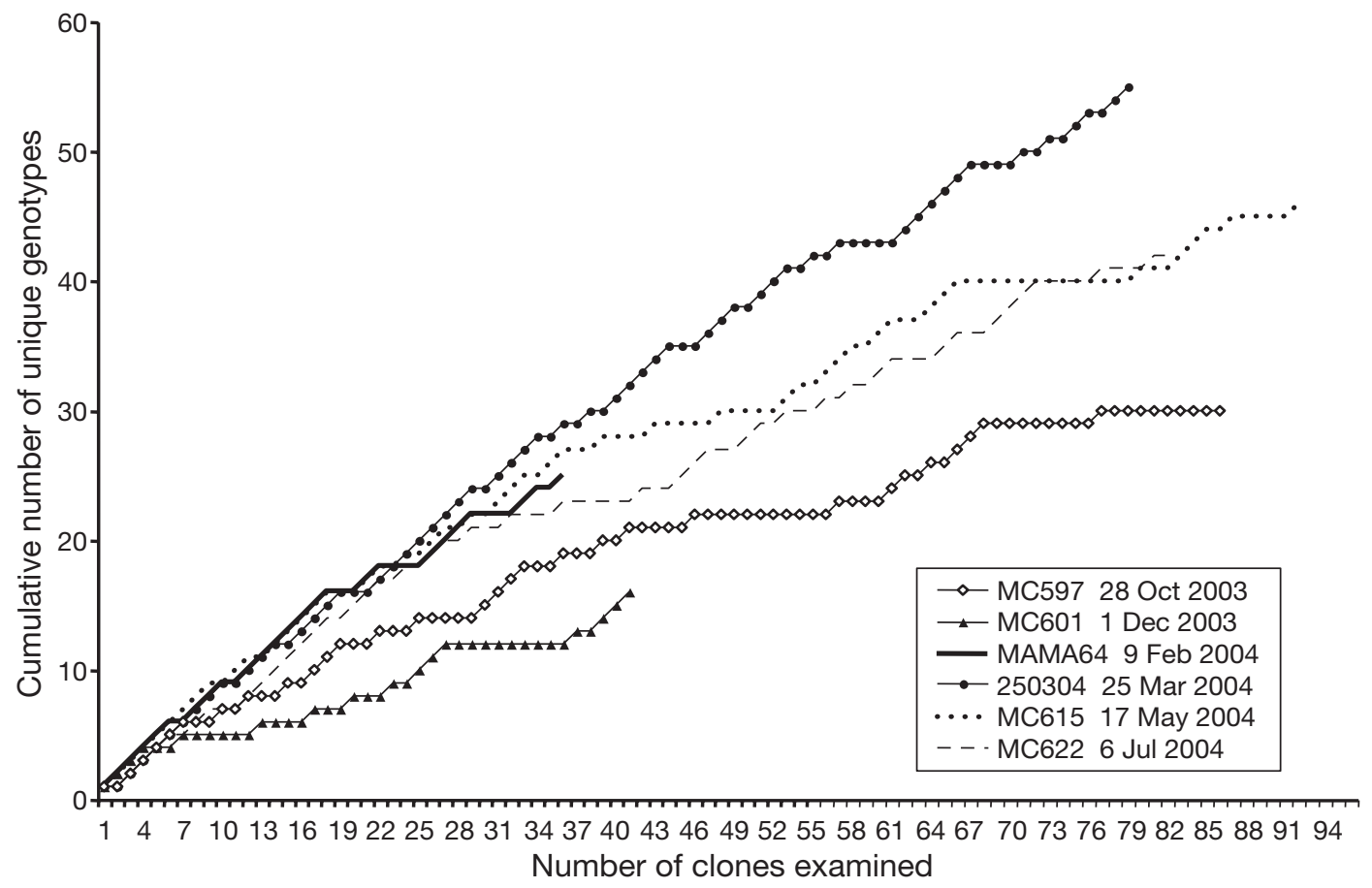

Fig. 4. Rarefaction curves for each of the 6 clone libraries calculated using the cumulative number of unique operational taxonomic units (OTUs) found against the number of clones examined to assess the saturation of each library 
Table 2. Clone library details, including the number of clones sequenced per library, the number of useful sequences per library, the number of operational taxonomic units (OTUs) identified and the coverage value for each library indicating how well the diversity within each sample was estimated by the library. $N_{c}$ : number of OTUs; $N$ : number of useful sequences

\begin{tabular}{|llcccc|}
\hline Library & Date & $\begin{array}{c}\text { No. of clones } \\
\text { sequenced }\end{array}$ & $N$ & $N_{\mathrm{c}}$ & $\begin{array}{c}\text { Coverage value } \\
1-\left(N_{\mathrm{c}} / N\right)(\%)\end{array}$ \\
\hline MC597 & 28 Oct 2003 & 96 & 86 & 30 & 65 \\
MC601 & 1 Dec 2003 & 47 & 41 & 10 & 75 \\
MAMA64 & 9 Feb 2004 & 47 & 36 & 19 & 47 \\
250304 & 25 Mar 2004 & 96 & 79 & 55 & 30 \\
MC615 & 17 May 2004 & 104 & 92 & 46 & 50 \\
MC622 & 6 Jul 2004 & 96 & 82 & 42 & 49 \\
Total & & 674 & 487 & 234 & \\
\hline
\end{tabular}

chloris sp. strain C94, Plagioselmis prolonga strain C27, Hemiselmis sp. strain C15, Rhodomonas sp. 3 strain C42, and Proteomonas sulcata strain C28 were all found in the various libraries. There were 7 unique cryptophyte OTUs, with the autumn library (MC597) containing the highest number (Table 3).

Several of the chrysophyte OTUs appeared to be closely related to previously described environmental sequences from Helgoland (HE17) and the Arabian Sea (Fuller et al. 2006b) (Fig. 8). Unfortunately marine Chrysophyceae are little studied, and the lack of 16S rRNA gene sequences from

The class Prymnesiophyceae showed the greatest diversity in the clone libraries, with 114 distinct OTUs in 190 sequences (Table 3). Sequences similar to Emiliania huxleyi, Imantonia rotunda, Isochrysis cf. galbana, Phaeocystis cordata, P. jahnii, P. globosa and the genus Chrysochromulina could be identified (Figs. 5 \& 6). However, most of the sequences remained cryptic since phylogenetic analysis, which included known sequences from GenBank and several Chrysochromulina sequences obtained during this study, failed to identify close cultured relatives. Some indication of seasonal distribution of the OTUs emerged, e.g. sequences belonging to $P$. cordata, P. jahnii and P. globosa were not found in the 2 summer libraries. Each library contained OTUs that were only found in that library (unique OTUs). Of the 167 OTUs found, 129 were unique. The spring/ summer libraries (250304, MC615 and MC622) had higher numbers of unique OTUs, with the March and July libraries having 33 unique OTUs each (Table 3).

For the cryptophytes, many of the clone library sequences had close matches to known cultures, particularly those isolated from the Gulf of Naples (Cerino \& Zingone 2006) (Fig. 7). Sequences matching Crypto- plastids of this class makes identifying most of the OTUs difficult if not impossible. The MC615 library contained the most OTUs, 9 of which were unique (Table 3).

Phylogenetic analysis of OTUs from other algal classes (Fig. 9) identified diatoms related to Skeletonema in the winter libraries (MC597 and MC601). The remaining diatom sequences could not be specifically identified. A dictyochophyte sequence, MC61564, identified from the May clone library clustered within a clade that included several sequences found in clone libraries from a recent AMT15 cruise in the mid-Atlantic Ocean (A. Kirkham \& D. Scanlan pers. comm.) as well as with a strain of Mesopedinella arctica. In the February library there was 1 pelagophyte sequence, identical to a strain of Pelagomonas calceolata, RCC100, isolated from the North Pacific Ocean. A number of Prasinophyceae clade I sequences were also found that fell into 2 clades, one of which was not closely related to any known taxa and the other differing at only one position from the environmental clone OCS162 from an Oregon Coast study (Rappé et al. 1998). One sequence, MC622-32, which is closely related to the Cape Hatteras sequence OM270, formed a separate clade.

Table 3. Number of sequences per class per library (regular text) with the number of distinct operational taxonomic units (OTUs) per library (bold text) and the number of OTUs found in that particular library and not in the other 5 (italics)

\begin{tabular}{|c|c|c|c|c|c|c|c|}
\hline \multirow{2}{*}{ Class } & \multirow[b]{2}{*}{ MC597 } & \multirow[b]{2}{*}{ MC601 } & \multirow[b]{2}{*}{ MAMA64 } & \multirow{2}{*}{$\begin{array}{r}\text { - Library - } \\
250304\end{array}$} & \multirow[b]{2}{*}{ MC615 } & \multirow[b]{2}{*}{ MC622 } & \multirow[b]{2}{*}{ Total } \\
\hline & & & & & & & \\
\hline Bacillariophyceae & $5 / 2 / 1$ & $1 / \mathbf{1} / 0$ & $1 / \mathbf{1} / 1$ & $1 / \mathbf{1} / 1$ & 1/1/1 & $1 / \mathbf{1} / 1$ & $10 / 6 / 5$ \\
\hline Chrysophyceae & $10 / 7 / 5$ & - & - & $5 / 3 / 1$ & $25 / 14 / 9$ & $21 / 6 / 4$ & $61 / \mathbf{2 6} / 19$ \\
\hline Cryptophyceae & $50 / 11 / 4$ & $31 / 8 / 2$ & $10 / 4 / 0$ & $10 / 6 / 1$ & $33 / 3 / 0$ & $10 / 2 / 0$ & $144 / 16 / 7$ \\
\hline Dictyochophyceae & - & - & - & - & $1 / \mathbf{1} / 1$ & - & $1 / \mathbf{1} / 1$ \\
\hline OM270 & - & - & - & - & - & $1 / \mathbf{1} / 1$ & $1 / \mathbf{1} / 1$ \\
\hline Pelagophyceae & - & - & $1 / \mathbf{1} / 1$ & - & - & - & $1 / \mathbf{1} / 1$ \\
\hline Prasinophyceae I & $7 / 2 / 1$ & $1 / \mathbf{1} / 0$ & - & - & - & - & $8 / 2 / 1$ \\
\hline Prymnesiophyceae & $15 / \mathbf{1 0} / 6$ & $8 / 6 / 1$ & $24 / \mathbf{1 7} / 10$ & $63 / 43 / 30$ & $31 / 26 / 20$ & $49 / 31 / 27$ & 190/114/94 \\
\hline
\end{tabular}




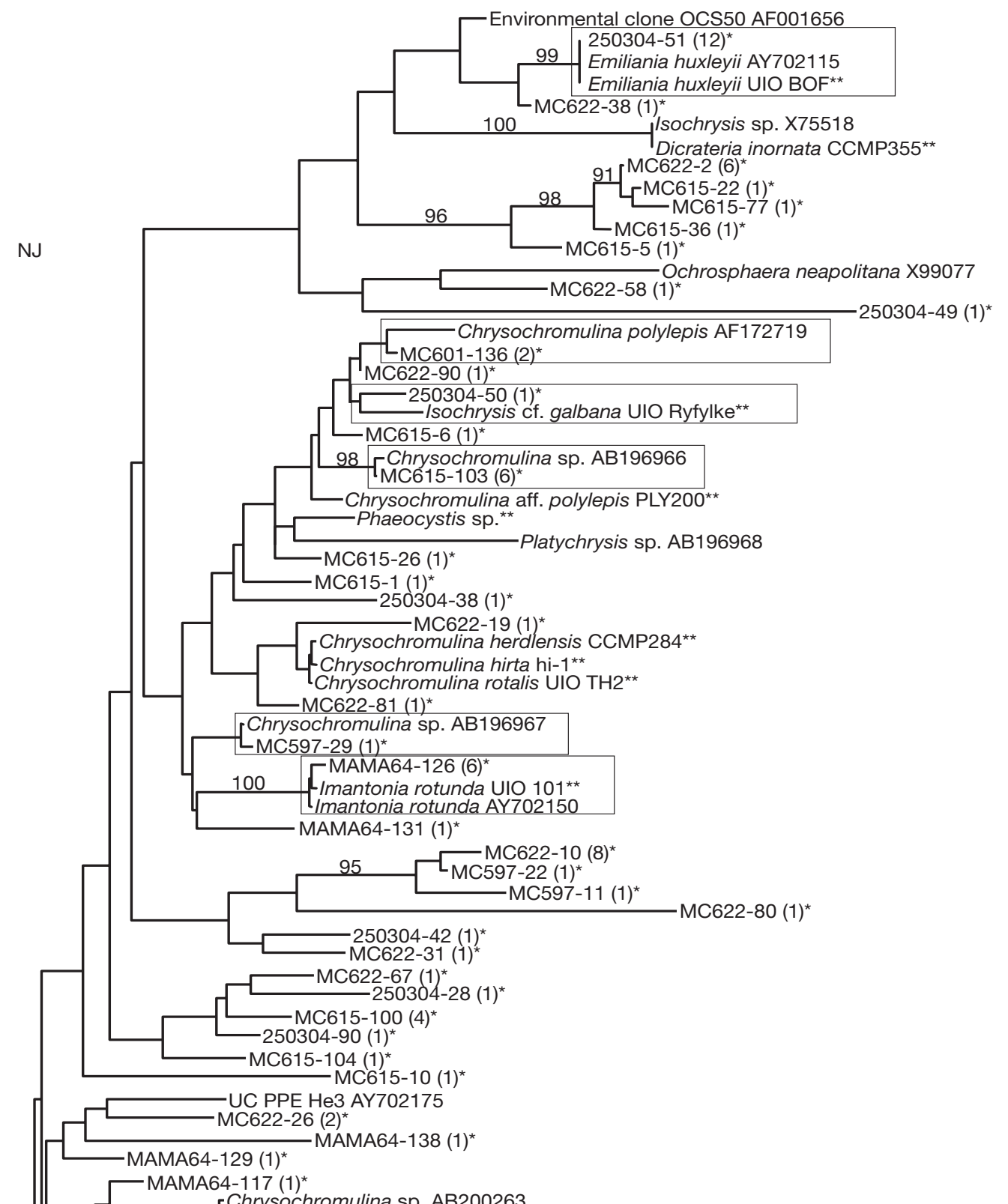

Fig. 5. Prymnesiophyceae neighbour-joining (NJ) tree (top half only, continues to Fig. 6 from black circle) with Maximum Likelihood (ML) parameter settings calculated by Modeltest (best fit model $\mathrm{TIM}+1+\mathrm{G} \mathrm{A}=0.2792, \mathrm{C}=0.1734, \mathrm{G}=0.2621$ and $\mathrm{T}$ $=0.2854 ; \mathrm{A} \Leftrightarrow \mathrm{C}=1, \mathrm{~A} \Leftrightarrow \mathrm{G}=6.1016, \mathrm{~A} \Leftrightarrow \mathrm{T}=1.4199$, $\mathrm{C} \Leftrightarrow \mathrm{G}=1.4199, \mathrm{C} \Leftrightarrow \mathrm{T}=9.0539$ and $\mathrm{G} \Leftrightarrow \mathrm{T}=1$; the positional rate variation across the alignment $\gamma=$ 0.3418 and the proportion of invariable sites $\mathrm{I}=$ 0.3162 ) showing the phylogenetic position of the Prymnesiophyceae genotypes found. Asterisked $\left({ }^{*}\right)$ sequences are those from the 6 Gulf of Naples libraries. Numbers in brackets refer to the total number of sequences corresponding to that genotype. Sequences with 2 asterisks refer to culture material sequenced during this study. Boxes indicate a grouping with a sequence from a known taxon. 


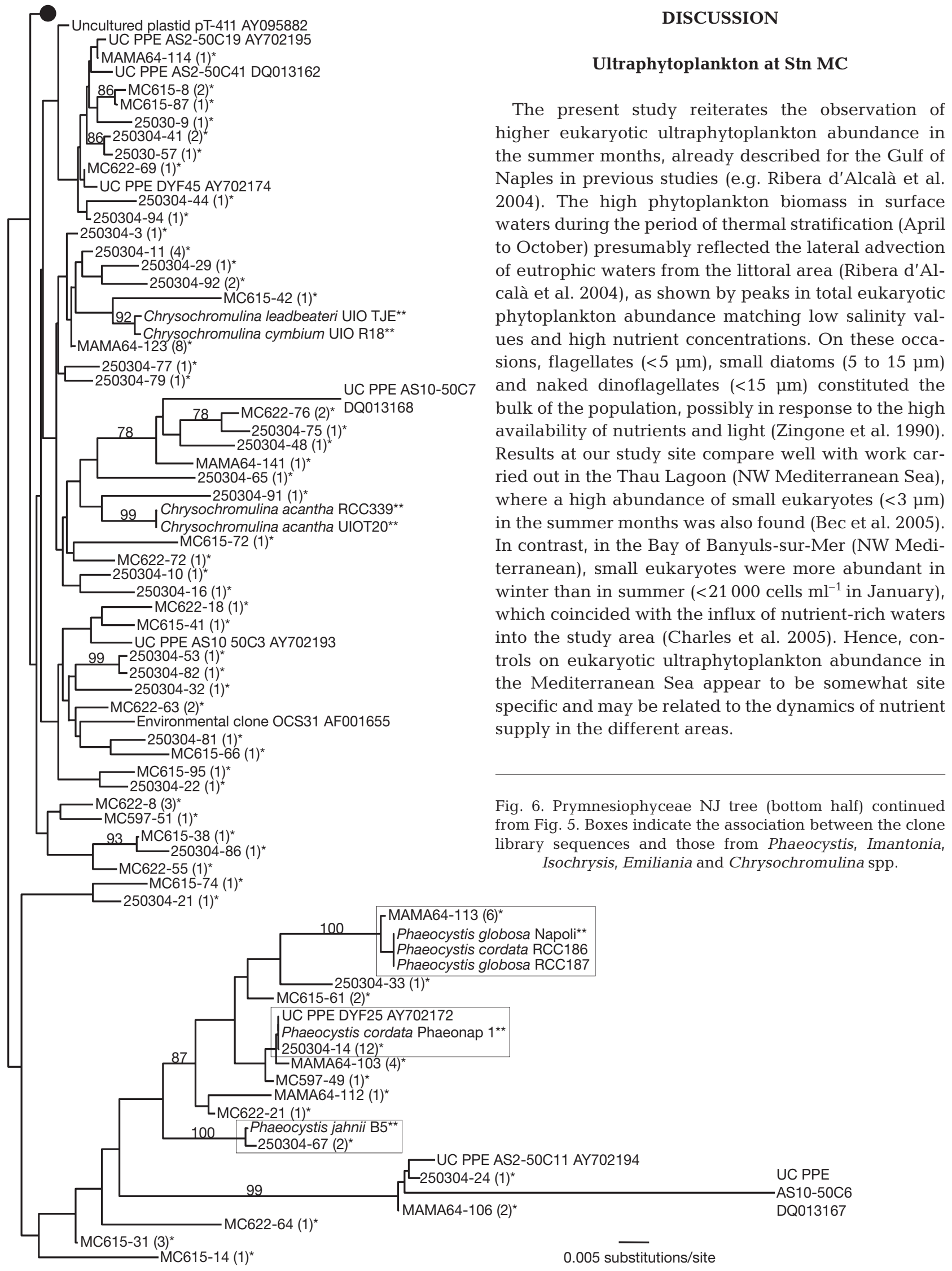




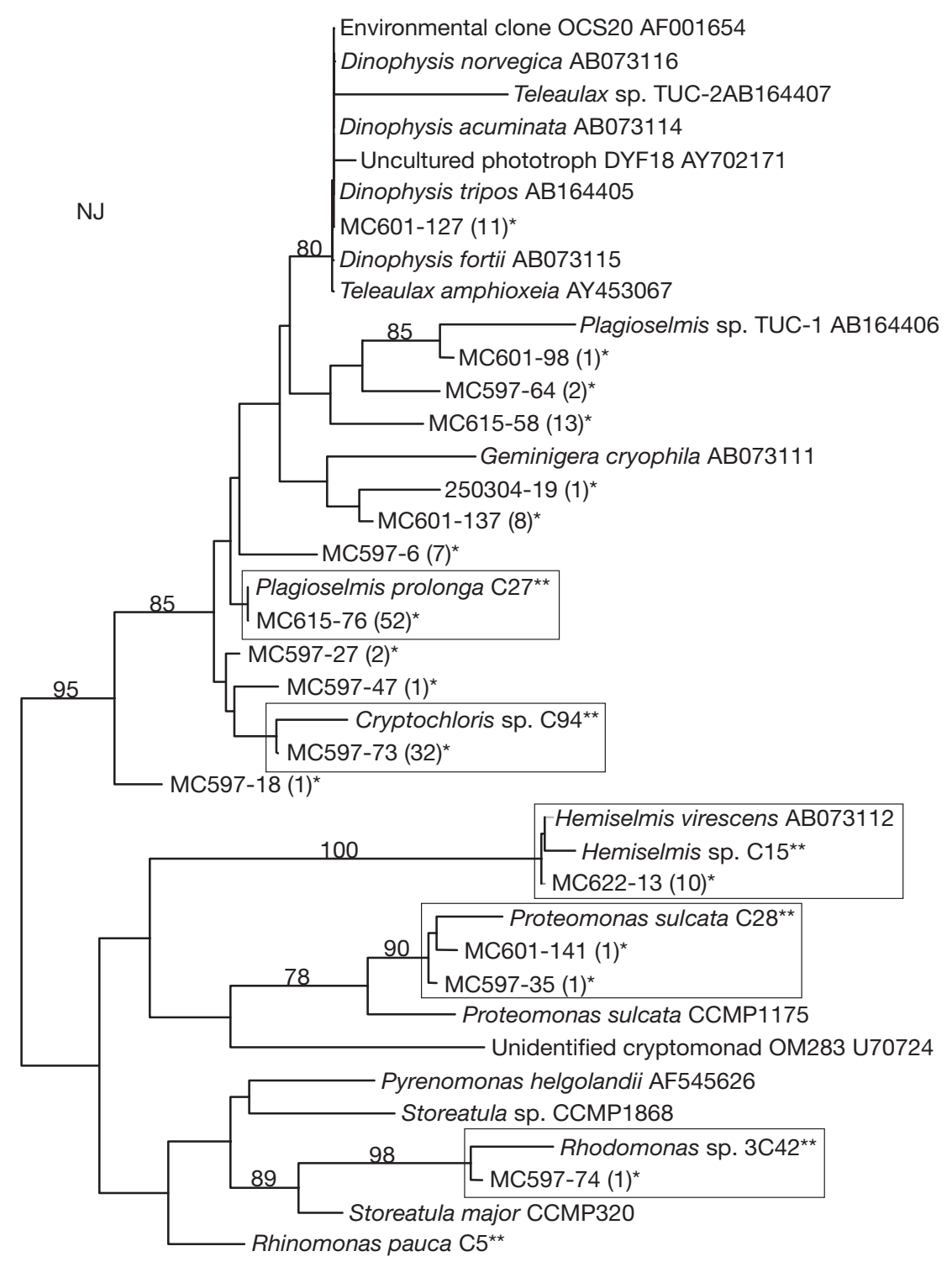

0.005 substitutions/site
Fig. 7. Cryptophyceae NJ tree constructed using ML settings (best fit model K81uf $+\mathrm{I}+\mathrm{G} \mathrm{A}=0.2735, \mathrm{C}=$ $0.2126, \mathrm{G}=0.2821$ and $\mathrm{T}=0.2319$; $\mathrm{A} \Leftrightarrow \mathrm{C}=1, \mathrm{~A} \Leftrightarrow \mathrm{G}=5.8410, \mathrm{~A} \Leftrightarrow \mathrm{T}=$ $0.3832, \mathrm{C} \Leftrightarrow \mathrm{G}=0.3832, \mathrm{C} \Leftrightarrow \mathrm{T}=$ 5.8410 and $\mathrm{G} \Leftrightarrow \mathrm{T}=1$; the positional rate variation across the alignment $\gamma=0.9072$ and the proportion of invariable sites $\mathrm{I}=0.802$ ) of $16 \mathrm{~S}$ rRNA gene sequences and using the OTUs from the 6 clone libraries (single asterisk). Numbers in brackets refer to the total number of sequences corresponding to each OTU. Bootstrap values are from 1000 replicates. Boxes indicate where there is a correspondence between the Cerino \& Zingone (2006) cultures and the sequences from the clone libraries

\section{Dot blot hybridisations}

The use of dot blot hybridisation probes on samples from the Gulf of Naples confirmed results from several previous studies and also highlighted the presence of groups that have not been previously detected. Both the Prymnesiophyceae and Cryptophyceae are abundant both in studies in the Gulf of Naples and elsewhere; however, the Chrysophyceae have been overlooked at sea. Relative hybridisation data for the Prymnesiophyceae showed this class to be present in the Gulf of Naples all year round, with no preference for any particular season. This class has previously been reported to be important in the Gulf of Naples (Zingone et al. 1990, 1999a, Ribera d'Alcalà et al. 2004), as well as in other regions (Thomsen et al. 1994, Moon-van der Staay et al. 2000, Fuller et al. 2006a,b).
Cryptophytes are also recognised as an important group in the marine environment. Their frequent recognition in fixed samples from Stn $\mathrm{MC}$ and results of a previous study based on serial dilution cultures (Cerino \& Zingone 2006) give support to the dot blot hybridisation data presented here. The only difference between the hybridisation data and those of the serial dilution cultures and phytoplankton counts is the high hybridisation signal in winter, when both the other methods show low abundance. It should be noted, though, that the hybridisation data reflect the percentage of PCR amplicons recognised by the Cryptophyceae-specific probe, and hence gives only a measure of relative abundance. Nonetheless, they show that Cryptophyceae are a significant proportion of the winter ultraphytoplankton community in the Gulf of Naples despite their low abundance. It is, therefore, 


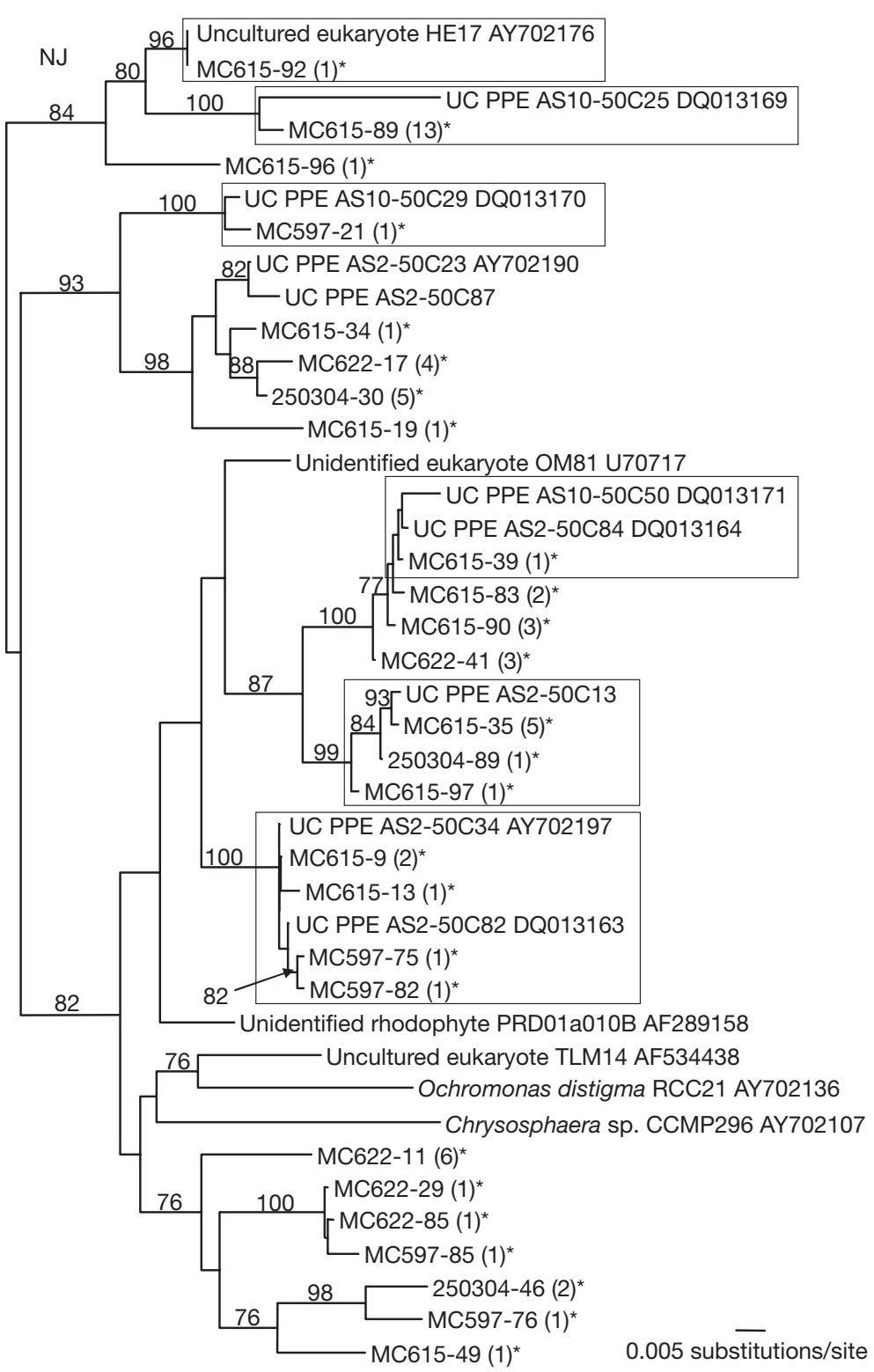

Fig. 8. Chrysophyceae NJ tree constructed using ML settings (best fit model $\operatorname{TrN}+1+\mathrm{G} \mathrm{A}=0.2896, \mathrm{C}=0.1789, \mathrm{G}=0.2739$ and $\mathrm{T}=0.2576 ; \mathrm{A} \Leftrightarrow \mathrm{C}$ $=1, A \Leftrightarrow G=3.9412, A \Leftrightarrow T=1, C \Leftrightarrow G=1, C \Leftrightarrow T=5.7361$ and $G \Leftrightarrow T=1$; the positional rate variation across the alignment $\gamma=0.6965$ and the proportion of invariable sites $\mathrm{I}=0.6104$ ) of $16 \mathrm{~S}$ rRNA gene sequences from the 6 Gulf of Naples clone libraries (single asterisk) including sequences from GenBank corresponding to cultures and clone libraries. Numbers in brackets refer to the total number of sequences corresponding to that genotype. Uppermost box shows the exact match between a Gulf of Naples sequence and a Helgoland clone library sequence. Other boxes indicate the groups containing sequences from the Gulf of Naples and Arabian Sea clone libraries

likely that the other methods underestimate this group; serial dilution cultures are affected by cultivation problems, and fixatives may poorly preserve cells of selected species of Cryptophyceae that may be present in winter.
Perhaps the most interesting result of this study is the unexpected importance of Chrysophyceae and the prevalence of this group in summer. This class is generally regarded as being more important in freshwater environments (Thomsen 1986) than at sea. In fact, in a relatively recent study (Sandgren et al. 1995) the only marine 'chrysophyte' discussed as being of any importance at sea was Aureococcus anophagefferens (Nicholls 1995), a species that has subsequently been transferred to the class Pelagophyceae (DeYoe et al. 1997). It is possible that this oversight is due to the fact that the pigment signature for the Chrysophyceae is the same as the diatoms and Prymnesiophyceae, all of which contain fucoxanthin and chlorophyll (chl) $C$, making it difficult to distinguish these classes in oceanographic studies that rely on pigments. A recent study along an Arabian Sea transect using both dot blot hybridisation and clone library data also revealed a dominance of chrysophytes along the whole length of the transect, but especially in more mesotrophic areas towards the Gulf of Oman and the Straits of Hormuz (Fuller et al. 2006a,b). Another recent study in Helgoland also recovered chrysophyte sequences (Medlin et al. 2006). It is possible that, with more extensive use of the Chrysophyceae probe, this group will be shown to be more widespread in the marine environment than previously thought.

\section{Clone libraries}

Overall, the clone library results closely matched the dot blot hybridisation data, in that the same 3 classes were recognised to be important at the study site by both methods. The sequence libraries were intentionally constructed from the selected samples to understand whether the rather low hybridisation values for those samples were due to an abundance of groups for which probes were not available. However, only a few sequences from groups lacking specific probes were present in the libraries, suggesting this was not the case.

The Prymnesiophyceae include approximately 280 described species (Graham \& Wilcox 2000), which is reflected in the high diversity found within the clone libraries for this class, and is also in keeping with other genetic studies from the Pacific Ocean (Moon-van der Staay et al. 2000) and the coast of Oregon (Rappé et al. 1998), where high numbers of prymnesiophyte OTUs were found. The total number of 


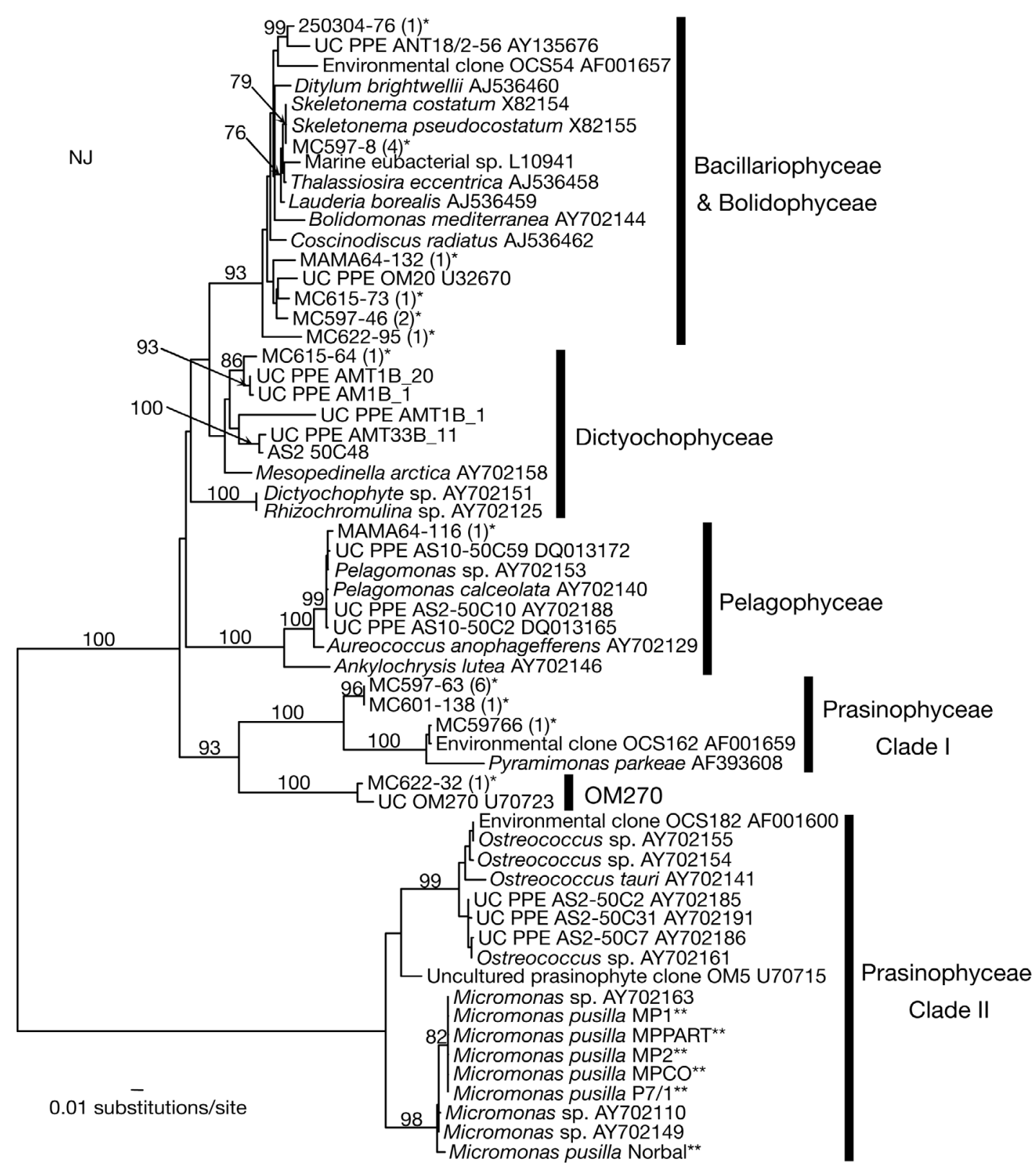

Fig. 9. NJ tree constructed using ML settings (best fit model GTR+1+G A = 0.2877, $C=0.1958, G=0.2724$ and $T=0.2441 ; A \Leftrightarrow C=$ 0.8922, $\mathrm{A} \Leftrightarrow \mathrm{G}=4.8909, \mathrm{~A} \Leftrightarrow \mathrm{T}=1.6615, \mathrm{C} \Leftrightarrow \mathrm{G}=0.5882, \mathrm{C} \Leftrightarrow \mathrm{T}=6.9923$ and $\mathrm{G} \Leftrightarrow \mathrm{T}=1$; the positional rate variation across the alignment $\gamma=0.7228$ and the proportion of invariable sites $I=0.4321$ ) showing the remaining 16S rRNA gene sequences from the 6 clone libraries (single asterisk), with representatives from cultures and other clone libraries from GenBank and ARB and from newly sequenced cultures from the Gulf of Naples ( 2 asterisks). Numbers in brackets refer to the total number of sequences corresponding to that genotype. Bootstrap values are from 1000 replicates

prymnesiophyte species seen in the Gulf of Naples is around 100 (A. Zingone unpubl. data), of which only Phaeocystis has been studied in any detail (Zingone et al. 1999a). Many of the sequences from the Gulf of Naples could not be identified below class level, which suggests a high number of undescribed taxa. However, the high number of unknown taxa seen in the clone libraries could well be a reflection of the lack of 16S rRNA gene sequences for known species. There are no $16 \mathrm{~S}$
rRNA gene sequences for Prymnesium, and only around $5 \%$ of the heterococcolithophores have been established in culture (Thomsen et al. 1994). In addition, the actual number of Chrysochromulina species may be more than 100 (Thomsen et al. 1994), of which several are picoplanktonic (e.g. C. apheles, C. minor, C. elegans and C. pyramidosa; see Thomsen et al. 1994). No 16S rRNA gene sequences are available for these species, and a culture is available for only one of them, C. minor. 
The presence of cryptophytes in all libraries concurs with data from the phytoplankton counts (data not presented) and from the dot blot hybridisations. This is the only class that had been studied previously in detail based on serial dilution cultures in the area (Cerino \& Zingone 2006), which allows for a comparison at the species level with results from different methods. Interestingly, the different OTUs found throughout the year matched the timing of species-specific blooms observed by Cerino \& Zingone (2006). The findings of 'Cryptochloris sp. C94-like' sequences in the winter libraries, Hemiselmis sp. C15-like sequences in July and 'Plagioselmis prolonga C27-like' sequences in all libraries, with highest numbers in October (MC597) and May (MC615), all perfectly match the information gathered through cultivation, supporting the idea that a succession of different cryptophyte species occurs in the Gulf of Naples throughout the year (Cerino \& Zingone 2006).

It is especially difficult to determine whether the diversity detected for the Chrysophyceae in the libraries reflects new diversity or a lack of sequences from known species. There are very few chrysophyte sequences available and only 3 autotrophic chrysophyte taxa have been previously identified in the MC LTEP: Ochromonas spp., retrieved using serial dilution cultures during summer months; Dinobryon coalescens, present in March and April; and D. faculiferum, found between April and September (D. Sarno \& A. Zingone unpubl. data). The latter 2 species are unlikely to pass through a $5 \mu \mathrm{m}$ filter due to the presence of a lorica much wider than the flagellated cells. The genus Ochromonas has been found to be polyphyletic and could include several different taxa, so it is possible that this group may account for some of the diversity encountered in the libraries. The fact that several Gulf of Naples chrysophyte OTUs show similarity to other available clone library sequences is interesting, particularly since they are from such different regions. MC615-92 shows $100 \%$ identity to a sequence from Helgoland (North Sea), where physical and biological conditions are markedly different from those found in the Mediterranean Sea. Other Gulf of Naples sequences show some similarity to Arabian Sea sequences (Fuller et al. 2006b), but not exact identity. The discovery of these sequences highlights the need for a more in-depth investigation of this class at sea.

The other classes found within the clone libraries shed light on the high taxonomic diversity within the ultraphytoplankton fraction. Interestingly, in both samples where the Skeletonema OTU was detected, the light microscopy counts show a high abundance of $S$. menzelii, which is generally solitary with a cell size between 2 and $5 \mu \mathrm{m}$. The distribution of OTUs belong- ing to other classes that are little studied within the Gulf of Naples is a stimulus for further study.

\section{Where is Micromonas?}

The widespread dominance of members of the prasinophyte order Mamiellales (clade II) (Not et al. 2004, 2005, Bec et al. 2005, Medlin et al. 2006) contrasts with the absence of this group in the present study. Micromonas pusilla, one of the most important and abundant species in the Mamiellales, has been shown to be abundant in the Gulf of Naples in studies using serial dilution cultures (Throndsen \& Zingone 1994, Zingone et al. 1999b) and epifluorescence microscopy (Zingone et al. 1999b). The lack of sequences from this group in the clone libraries may be due to either sampling or molecular detection problems. The fact that 2 clone libraries constructed using the PLA491F-1313R primer pair and $3 \mathrm{mM} \mathrm{MgCl}_{2}$ concentration for the PCR reaction found several Mamiellales sequences (data not shown) suggests that the latter is probably the case. As increased $\mathrm{MgCl}_{2}$ concentration decreases the specificity of the PCR primers, these libraries also contained cyanobacterial and bacterial sequences. However, the implication is that clade II prasinophytes may not be well represented using this primer pair, and that there is some trade-off between excluding cyanobacteria and bacteria and including all eukaryotes.

There is evidence that other green algae are also important between May and July in surface waters of the Gulf of Naples as shown by higher concentrations of chl $b$ and violaxanthin (Santarpia 2005), 2 pigments that are found in all groups of Prasinophyceae and Chlorophyceae (Sym \& Pienaar 1993). The fact that Prasinophyceae sequences were only detected in the winter libraries (October and December) does not help clarify what these green algae are.

Acknowledgements. The authors thank B. Edvardsen and F. Cerino for the provision of DNA from cultures, A. Kirkham for the Dictyochophyceae clone library sequences, N. Fuller and S. Mazard for their help with the hybridizations and W. Kooistra for his advice on phylogenies. The crew of the RV 'Vettoria', members of the Office of Management and Ecology of Temperate and Polar Coastal Areas, SZN, and of the Servizio di Biologia Molecolare, SZN, particularly E. Mauriello and M. Borra, are also thanked. This work is part of the $\mathrm{PhD}$ programme of S.M.M. (Open University London, UK; Stazione Zoologica 'A. Dohrn', Napoli, Italy); her work at the University of Warwick was supported by the NERC and Society for General Microbiology President's Fund Grant for a short research visit. This publication contributes to the EU Networks of Excellence MarBef 'Marine Biodiversity and Ecosystem Functioning' (contract no. GOCE-CT-2003-505446) and Marine Genomics Europe (contract no. GOCE-CT-2004-505403). 


\section{LITERATURE CITED}

Andersen RA, Bidigare RR, Keller MD, Latasa M (1996) A comparison of HPLC pigment signatures and electron microscopic observations for oligotrophic waters of the North Atlantic and Pacific Oceans. Deep-Sea Res II 43: 517-537

Bec B, Husseini-Ratrema J, Collos Y, Souchu P, Vaquer A (2005) Phytoplankton seasonal dynamics in a Mediterranean coastal lagoon: emphasis on the picoeukaryote community. J Plankton Res 27:881-894

Carrada GC, Hopkins TS, Bonaduce G, Ianora A and others (1980) Variability in the hydrographic and biological features of the Gulf of Naples. PSZN I: Mar Ecol 1:105-120

Casotti R, Brunet C, Graziano A (2001) Ultraplankton of the Gulf of Naples by flow cytometry. In: Faranda RM, Guglielmo L, Spezie G (eds) Mediterranean ecosystems: structures and processes. Springer-Verlag Italia, Rome, p 171-180

Cerino F, Zingone A (2006) A survey of cryptomonad diversity and seasonality at a coastal Mediterranean site. Eur J Phycol 41:363-378

Charles F, Lantoine F, Brugel S, Chrétiennot-Dinet MJ, Quiroga I, Rivière B (2005) Seasonal survey of the phytoplankton biomass, composition and production in a littoral NW Mediterranean site, with special emphasis on the picoplanktonic contribution. Estuar Coast Shelf Sci 65: 199-212

DeYoe HR, Stockwell DA, Bidigare RR, Latasa M, Johnson PW, Hargraves PE, Suttle CA (1997) Description and characterization of the algal species Aureoumbra lagunensis gen. et sp. nov. and referral of Aureoumbra and Aureococcus to the Pelagophyceae. J Phycol 33:1042-1048

Díez B, Pedrós-Alió C, Marsh TL, Massana R (2001a) Application of denaturing gradient gel electrophoresis (DGGE) to study the diversity of marine picoeukaryotic assemblages and comparison of DGGE with other molecular techniques. Appl Environ Microbiol 67:2942-2951

Díez B, Pedrós-Alió C, Massana R (2001b) Study of genetic diversity of eukaryotic picoplankton in different oceanic regions by small-subunit rRNA gene cloning and sequencing. Appl Environ Microbiol 67:2932-2941

Doyle JJ, Doyle JL (1987) A rapid DNA isolation procedure from small quantities of fresh leaf tissues. Phytochem Bull 19:11-15

Edwards U, Rogall T, Blocker H, Emide M, Bottger EC (1989) Isolation and direct complete nucleotide determination of entire genes. Characterization of a gene coding for $16 \mathrm{~S}$ ribosomal RNA. Nucleic Acids Res 17:7843-7853

Fuller NJ, Marie D, Partensky F, Vaulot D, Post AF, Scanlan DJ (2003) Clade-specific 16S ribosomal DNA oligonucleotides reveal the predominance of a single marine Synechococcus clade throughout a stratified water column in the Red Sea. Appl Environ Microbiol 69:2430-2443

Fuller NJ, Tarran GA, Cummings DG, Woodward EMS, Orcutt KM, Yallop M, Le Gall F, Scanlan DJ (2006a) Molecular analysis of photosynthetic picoeukaryote community structure along an Arabian Sea transect. Limnol Oceanogr 51:2502-2514

Fuller NJ, Campbell C, Allen DJ, Pitt FD, Zwirglmaier K, Le Gall F, Vaulot D, Scanlan DJ (2006b) Analysis of photosynthetic picoeukaryote diversity at open ocean sites in the Arabian Sea using a PCR biased towards marine algal plastids. Aquat Microb Ecol 43:79-93

Graham LE, Wilcox LW (2000) Algae. Prentice-Hall, New York

Guillou L, Chrétiennot-Dinet MJ, Medlin LK, Claustre H,
Loiseaux de Goer S, Vaulot D (1999) Bolidomonas: a new genus with two species belonging to a new algal class, the Bolidophyceae (Heterokonta). J Phycol 35:368-381

Jeffrey SW, Wright SW (1994) Photosynthetic pigments in the haptophytes. In: Green JC, Leadbeater BSC (eds) The haptophyte algae. Oxford University Press, Oxford, p 111-133

Johnson PW, Sieburth JM (1982) In-situ morphology and occurrence of eukaryote phototrophs of bacterial size in the picoplankton of estuarine and oceanic waters. J Phycol 18:318-327

Li WKW, Subba Rao DV, Harrison WG, Smith JC, Cullen JJ, Irwin B, Platt T (1983) Autotrophic picoplankton in the tropical ocean. Science 219:292-295

Li WKW, Zohary T, Yacobi YZ, Wood AM (1993) Ultraplankton in the eastern Mediterranean Sea: towards deriving phytoplankton biomass from flow cytometric measurements of abundance, fluorescence and light scatter. Mar Ecol Prog Ser 102:79-87

Marino D, Modigh M, Zingone A (1984) General features of phytoplankton communities and primary production in the Gulf of Naples and adjacent waters. In: Holm-Hansen $\mathrm{O}$, Bolis L, Gilles R (eds) Marine phytoplankton and productivity. Springer-Verlag, Berlin, p 89-100

Massana R, Guillou L, Díez B, Pedrós-Alió C (2002) Unveiling the organisms behind novel eukaryotic ribosomal DNA sequences from the ocean. Appl Environ Microbiol 68: $4554-4558$

McDonald SM, Sarno D, Zingone A (2007) Identifying Pseudo-nitzschia species in natural samples using genusspecific PCR primers and clone libraries. Harmful Algae 6:849-860, doi:10.1016/j.hal.2007.03.003

Medlin LK, Metfies K, Mehl H, Wiltshire K, Valentin K (2006) Picoeukaryotic plankton diversity at the Helgoland time series site as assessed by three molecular methods. Microb Ecol 52:53-71

Moon-van der Staay SY, van der Staay GWM, Guillou L, Vaulot D, Claustre H, Medlin LK (2000) Abundance and diversity of prymnesiophytes in the picoplankton community from the equatorial Pacific Ocean inferred from $18 \mathrm{~S}$ rRNA sequences. Limnol Oceanogr 45:98-109

Moon-van der Staay SY, De Wachter R, Vaulot D (2001) Oceanic 18S rRNA sequences from picoplankton reveal unsuspected eukaryotic diversity. Nature 409:607-610

Nicholls KH (1995) Chrysophyte blooms in the plankton and neuston of marine and freshwater systems. In: Sandgren CD, Smol JP, Kristiansen J (eds) Chrysophyte algae. Cambridge University Press, Cambridge, p 181-213

Not F, Latasa M, Marie D, Cariou T, Vaulot D, Simon N (2004) A single species, Micromonas pusilla (Prasinophyceae), dominates the eukaryotic picoplankton in the western English Channel. Appl Environ Microbiol 70:4064-4072

Not F, Massana R, Latasa M, Marie D and others (2005) Late summer community composition and abundance of photosynthetic picoeukaryotes in Norwegian and Barents Sea. Limnol Oceanogr 50:1677-1686

Potter D, Lajeunesse TC, Saunders GW, Andersen RA (1997) Convergent evolution masks extensive biodiversity among marine coccoid picoplankton. Biodivers Conserv 6:99-107

Rappé MS, Kemp PF, Giovannoni SJ (1995) Chromophyte plastid 16S ribosomal RNA genes found in a clone library from Atlantic Ocean seawater. J Phycol 31:979-988

Rappé MS, Suzuki MT, Vergin KL, Giovannoni SJ (1998) Phylogenetic diversity of ultraplankton plastid smallsubunit rRNA genes recovered in environmental nucleic acid samples from the Pacific and Atlantic coasts of the United States. Appl Environ Microbiol 64:294-303 
Ribera d'Alcalà M, Conversano F, Corato F, Licandro P and others (2004) Seasonal patterns in plankton communities in a pluriannual time series at a coastal Mediterranean site (Gulf of Naples): an attempt to discern recurrences and trends. Sci Mar 68(Suppl 1):65-83

Romari K, Vaulot D (2004) Composition and temporal variability of picoeukaryote communities at a coastal site of the English Channel from 18S rRNA sequences. Limnol Oceanogr 49:784-798

Sandgren CD, Smol JP, Kristiansen J (eds) (1995) Chrysophyte algae. Cambridge University Press, Cambridge

Santarpia I (2005) Ultraphytoplankton in marine ecosystems: from seasonal cycle to short term responses. PhD thesis, Università degli Studi di Napoli Federico II, Naples

Sym SD, Pienaar RN (1993) The class Prasinophyceae. Prog Phycol Res 9:281-276

Thomsen HA (1986) A survey of the smallest eucaryotic organisms of the marine phytoplankton. In: Platt $\mathrm{T}, \mathrm{Li}$ WKW (eds) Photosynthetic picoplankton, Vol 214. Dep Fish Oceans, Ottawa, p 121-158

Thomsen HA, Buck KR, Chavez FP (1994) Haptophytes as

Editorial responsibility: Dittmar Hahn,

San Marcos, Texas, USA components of marine phytoplankton. In: Green JC, Leadbeater BSC (eds) The haptophyte algae. Oxford University Press, Oxford, p 187-208

Throndsen J, Zingone A (1994) Micronomads of the Mediterranean Sea. G Bot Ital 128:1031-1044

West NJ, Scanlan DJ (1999) Niche-partitioning of Prochlorococcus populations in a stratified water column in the eastern North Atlantic Ocean. Appl Environ Microbiol 65: $2585-2591$

Zingone A, Montresor M, Marino D (1990) Summer phytoplankton physiognomy in coastal waters of the Gulf of Naples. PSZN I: Mar Ecol 11:157-172

Zingone A, Chrétiennot-Dinet MJ, Lange M, Medlin L (1999a) Morphological and genetic characterization of Phaeocystis cordata and Phaeocystis jahnii (Prymnesiophyceae), two new species from the Mediterranean Sea. J Phycol 35:1322-1337

Zingone A, Sarno D, Forlani G (1999b) Seasonal dynamics of Micromonas pusilla (Prasinophyceae) and its viruses in the Gulf of Naples (Mediterranean Sea). J Plankton Res 21:2143-2159

Submitted: October 16, 2006; Accepted: September 4, 2007 Proofs received from author(s): November 12, 2007 